is on statistical methods for research on diurnal variations, and contains both important conclusions and interesting suggestions for future work in this difficult field.

THE paper contributed by Prof. L. Vegard is a brief account of an investigation of the temperature of the auroral region by the use of the rotational series of the negative nitrogen bands, shown on auroral spectra obtained by long-continued intermittent exposures over several weeks or months. The results obtained in two different ways agree in giving the value of $240^{\circ} \mathrm{K}$. This is much lower than the high temperature for this region first proposed by Lindemann and Dobson on meteoric evidence, and confirmed by the abnormal propagation of sound, by reflection at a height of about $40 \mathrm{~km}$. In this connexion, Vegard mentions experiments he has made tending to show that the laws of propagation of sound at low densities are different from those that apply at normal densities. The paper is an interesting contribution to a controversial subject. Another interesting paper, by Prof. V. F. Hess, reviews the present state of knowledge concerning cosmic rays, mentions the co-operative scheme of work started on his initiative in order to examine whether the irregular fluctuations of the rays occur simultaneously in different places, and gives some preliminary results of the work of his cosmic ray observatory on the Hafelekar ridge, near Innsbruck.

\section{Exploration of the Upper Atmosphere}

THE International Commission for the Exploration of the Upper Atmosphere has recently published the collected results of upper air work done during 1924, under the title "Comptes Rendus des Jours Internationaux, 1924". As in the case of the first and pioneer volume of the kind, for 1923 , the compilation has been made under the supervision of Sir Napier Shaw, honorary president of the Commission; the 1924 volume has unfortunately been delayed by his illness, and by financial difficulties. The latter have been lightened by the use of the Replika process in the production of the volume, the price of which is 45s. ; the later volumes (of which that for 1925 has already appeared, under the title "Ergebnisse der Aerologischen Messungen, 1925"), are being published by Prof. Hergesell, president of the Commission, at the regrettably high price of 60 gold marks. The present volume is in two parts, one containing tabular details of the ascents of sounding balloons, together with synoptic charts for the international days, and the other containing 'tephigrams' representing graphically the results of individual ascents.

\section{Rainfall and Water Supply}

IN an article by F. J. Garland entitled "Rainfall and Water Supply" in Progress and the Scientific Worker for September and October 1932, stress is laid on the importance of the work of the voluntary rainfall observers whose records supply a very large proportion of the material for the annual volumes of "British Rainfall", the old-established publication of the British Rainfall Organization now compiled by the Meteorological Office. The article contains interesting facts about springs and artesian wells, and some particulars about the practical side of the engineering problems involved in conveying water to distant towns from catchment areas. On these subjects the writer is on his own ground, but when he passes to purely meteorological matters connected with rainfall, some very inaccurate statements are made. Thus, he says (p. 49) that the greatest recorded rainfall in England in 24 hours may be taken to be about three inches. The annual volumes of "British Rainfall" show however that falls greatly in excess of three inches occur in most years; that 9.56 in. fell in one day in 1917 at Bruton, Somerset, and 9.40 in. at Cannington once in 1924. The incorrect statement is also made that there is no satisfactory record of the amount of rain that fell during the Louth cloudburst of May 29, 1920, whereas, thanks to the records of voluntary observers, enough information was available for the rainfall to be mapped by means of isohyetal lines for the whole area of the storm, and this information is available not only in "British Rainfall" for that year, but also in the report of the special investigation undertaken by the Meteorological Office (Professional Note, No. 17, of the Meteorological Office. London: H.M. Stationery Office).

\section{Scots Pine Timber}

Buldetin No. 15 (Dec. 1931) of the Forest Products Research Laboratory deals with a detailed analysis of "The Timber of Home Grown Scots Pine (Pinus sylvestris)". The primary considerations in connexion with the utilisation of home grown Scots pine, the resources of which timber in Great Britain were so depleted during the War, are the general grade of the timber and its mechanical properties. The investigations which have been undertaken at the Laboratory indicate that the home grown timber in different localities varies considerably in weight, and ranges from 25 to $45 \mathrm{lb}$. per cub. ft. at a moisture content of 12-15 per cent. The darker colour of the heart wood, which is an indication of the durability, is more marked in the home grown than in the imported timber, while the percentage of heart wood is depen. dent on locality and age. The average rate of growth of the timber in the four consignments examined varied from 4 to 23 and the average of individual consignments from 7 to 12 rings per inch. The bulletin deals in sections with structure, seasoning, mechanical and physical properties, antiseptic treatment, working and utilisation, and pests of the species. One of the problems facing the newly formed plantations of pine in Great Britain is to find or create a market for the small material which will come out in the early indispensable thinnings ; while, it is pointed out, to produce best quality timber the time must be given to obtain at least 12 rings to the inch radius, and for lower grades at least 9 rings per inch are necessary. Straight-grained timber, as free from knots as possible, is demanded by the markets.

No. 3295, Vol. 130] 